\section{Desbravando antigos e novos territórios}

\author{
Renato Sérgio de Lima*
}

MARQUES, E.; TORRES, H. (Orgs.).
São Paulo: segregação, pobreza e
desigualdades sociais. São Paulo:
Editora Senac, 2005 (329 páginas).

Lançado em 2005, o livro São Paulo: segregação, pobreza e desigualdades sociais insere-se num esforço de conformação de um campo de pesquisa que recoloca o território tanto como unidade de análise quanto como recurso analítico capaz de enfrentar a multiplicidade do social, oferecendo uma possibilidade para a compreensão mais ampla de questões essenciais da estrutura da sociedade brasileira.

Aspectos espaciais, demográficos e socioeconômicos da pobreza são, assim, articulados a partir do enfoque territorial. Com isso, os autores organizam o livro em três grandes partes e doze capítulos, destacando-se a preocupação com o equilíbrio entre questões conceituais, características sociais e, ainda, aspectos políticos, demonstrada no cuidado de as partes terem, todas, quatro capítulos.

Ao longo do livro, esses três eixos permitem que o leitor extrapole as análises sobre pobreza e desigualdade social para além de uma simples relação causa e efeito, considerando São Paulo de modo multidimensional e mutifacetado, por meio de variáveis como segregação ou heterogeneidade de formas de ocupação e organização do espaço urbano.

Na primeira parte são discutidas questões que delimitam o universo de investigação e as técnicas adotadas. No capítulo 4, por exemplo, Haroldo Torres reflete sobre a fronteira paulistana, caracterizada por altas taxas de crescimento demográfico e não sujeita, necessariamente, às divisas geográficas e políticas dos municípios e/ou às periferias. Tanto que, posteriormente, a discussão será retomada no último capítulo, ao se abordar o tema metropolitano. A segunda e a terceira partes se distinguem pela ênfase dada ora às condições de vida (segunda parte) ora à interação de atores sociais com a pobreza espacialmente determinada (terceira parte), mas ambas são construídas a partir de análises de casos e situações sociais específicas.

Desse modo, o livro é, sem dúvida, a tradução mais acabada de uma aposta teórica e de um projeto de investigação que objetiva consolidar a produção sobre a metrópole no Brasil e, nessa direção, pautar a construção de novas agendas de pesquisa na área, numa tentativa declarada de atualizar e reforçar a liderança do Cebrap, inaugurada com a publicação de São Paulo, 1975: crescimento e pobreza.

Trata-se, porém, de uma abordagem muito influenciada pela sociologia norteamericana, pela qual os estudos pioneiros da Escola de Chicago são atualizados e, com o apoio de tecnologias de georreferenciamento, seus temas ganham nova centralidade. Para tanto, os textos utilizam séries históricas de dados disponíveis, localizando no tempo os fenômenos que determinam a heterogeneidade da pobreza na metrópole. Ao mesmo tempo, num interessante uso das metodologias de SIG (Sistemas de Informações Geográficas), o espaço é incluído como o terceiro ponto da matriz tridimensional de dados que serve às análises empreendidas.

Diante da promessa deste poderoso recurso metodológico, Haroldo Torres e Eduardo Marques lançam-se no desafio de compreender a pobreza para além das macronarrativas dos modelos da sociologia clássica da área no Brasil, procurando estabelecer balizas ou parâmetros que colaborem na explicação de um cenário social fragmentado, heterogêneo, segregador e, por conseguinte, produtor de processos

\footnotetext{
* Chefe da Divisão de Estudos Socioeconômicos da Fundação Seade e coordenador-chefe do Núcleo de Pesquisas do Instituto Brasileiro de Ciências Criminais - IBCCrim. Doutor em Sociologia pela Universidade de São Paulo.
} 
contínuos de reificação e retroalimentação de desigualdades e identidades.

Assim, eles são não apenas os organizadores da publicação, mas também autores ou co-autores de nove dos doze capítulos do livro. Os demais capítulos, de autoria de Sandra Gomes, Cláudio Amitrano, Ronaldo Almeida, Tiaraju D'Andrea e Renata Bichir filiam-se a esta aposta teórica e acrescentam ao livro relatos de situações específicas sobre a influência espacial na vida cotidiana dos indivíduos residentes em áreas consideradas de alta vulnerabilidade social (vulnerabilidade à pobreza) e na agenda das políticas públicas setoriais.

Por sinal, no capítulo de Ronaldo Almeida e Tiaraju D'Andrea, encontra-se uma importante constatação teórica-metodológica que, ampliada, serve para descrever o livro. Tais autores lembram que, ao analisar a favela de Paraisópolis, variáveis de diferentes níveis puderam ser identificadas, mas o caráter positivo ou negativo que porventura possa ser atribuído a cada uma delas dependerá, por um lado, de uma postura relacional ao conjunto da cidade e, por outro, do conjunto dos bairros ou lugares pobres de São Paulo.

Em outras palavras, se a segregação em São Paulo é constituída por características que a associam à pobreza, será no estudo comparado de situações congêneres que os problemas sociais e econômicos da cidade poderão ser identificados e enfrentados. O foco vai do universal ao particular e desse para a explicação das relações sociais na metrópole. Esse mesmo trajeto é percorrido pelo capítulo cinco, de Haroldo Torres, Maria Paula Ferreira e Sandra Gomes, em que se analisa como a formação escolar é influenciada pelas características socioeconômicas da área de residência dos indivíduos e, ainda, de que forma essa influência sofre o efeito das áreas vizinhas às de moradia dos indivíduos, controlados alguns atributos individuais (raça, sexo, etc.).

A perspectiva relacional está presente, em maior ou menor grau, em todos os capítulos do livro e é ela quem parece dar o tom do debate. Não obstante a unidade de análise dos textos ser o território, a idéia de que ele tem que ser tomado relacionalmente exige uma procura constante por variáveis intervenientes que o dotem de significado. O exercício de análise é, em conseqüência, o reconhecimento de diferenças e a investigação dos papéis que elas exercem na organização das condições de vida da população.

Em paralelo, o Estado foi tomado como um ator fundamental na organização do espaço da metrópole e, nessa linha, medir a influência de suas ações tem o duplo caráter de dar significado aos dados e, sobretudo, o de perceber os sentidos da política. Isso é feito em várias passagens do livro, mas os dois últimos capítulos recolocam a importância das políticas públicas - sejam municipais, estaduais ou federais na compreensão dos principais fenômenos presentes em São Paulo.

Entretanto, exatamente nesse campo, algumas lacunas importantes fazem-se presentes, relacionadas, mais especificamente, à questão da violência e às políticas de segurança pública, que somente são lembradas em algumas poucas referências no livro, em especial quando do diálogo com a obra de Teresa Caldeira, mas que atravessam e dotam de significado muitos dos padrões das relações sociais das metrópoles no Brasil.

A ausência desse tema no livro não pode ser considerada, propriamente, uma conseqüência do modelo de análise adotado. Isso porque a violência, enquanto fenômeno social, é uma das variáveis com maior aderência ao território que a sociologia, desde os seus primórdios, já estudou.

Assim, não abordá-la e/ou não tratá-la no livro deixou passar a possibilidade de compreensão de questões como, por exemplo, a associação entre território e violência juvenil, ainda uma pauta de pesquisas em aberto no país. No limite, deixou passar a oportunidade de aproximar linhas de pesquisas que têm no território o seu ponto de intersecção. Enfim, fazem falta textos contemplando tal tema e/ou testando, entre outras, as associações entre território, pobreza, população, desigualdades e violência.

Dito tudo isso, creio que o livro tem o potencial de ser obra de referência para os 
estudos urbanos e, se tomado como o esforço de um grupo de pesquisa em disseminar de forma transparente seus pressupostos e objetivos, possui o mérito de se constituir em um balanço de quase todas as principais e atuais questões postas ao debate sobre o espaço urbano no Brasil.

Recebido para publicação em 05/05/2006. Aceito para publicação em 09/06/2006. 